\title{
Conflict in Yemen: From Ethnic Fighting to Food Riots
}

\author{
Andreas Gros, Alexander Gard-Murray and Yaneer Bar-Yam \\ New England Complex Systems Institute \\ 238 Main St. Suite 319 Cambridge MA 02142, USA
}

(Dated: July 24, 2012)

\begin{abstract}
Yemen is considered a global terrorist base for Al-Qaeda and in recent years rampant violence is threatening social order. Here we show that the socio-economic origins of violence recently changed. Prior to 2008, violence can be attributed to inter-group conflict between ethnically and religiously distinct groups. Starting in 2008, increasing global food prices triggered a new wave of violence that spread to the endemically poor southern region with demands for government change and economic concessions. This violence shares its origins with many other food riots and the more recent Arab Spring. The loss of social order and the opportunities for terror organizations can be best addressed by directly eliminating the causes of violence. Inter-group violence can be addressed by delineating within-country provinces for local autonomy of ethnic and religious groups. The impact of food prices can be alleviated by direct food price interventions, or by addressing the root causes of global food price increases in US policies that have promoted conversion of corn to ethanol and commodity speculation. Addressing the food prices is the most urgent concern as a new bubble in food prices has been projected to begin before the end of 2012 .
\end{abstract}


Violence has been common in Yemen since the founding of a modern state in the southern Arabian peninsula nearly 100 years ago [1, 2], but recent attacks and social disruption are particularly severe [3-5]. Yemen is one of the global bases of Al-Qaeda [6-10], with the attacks on the USS Cole in 2000 and American Embassy in 2008 as the most well known local incidents. Yemeni Al-Qaeda has also been involved in global terror activities including an alleged attempt to bomb a Detroit-bound plane on Christmas Day of 2009. At the beginning of that year, Yemeni Al-Queda joined with the smaller Saudi Al-Queda to form Al Queda of the Arabian Peninsula (AQAP). The current social disruption increases concerns that Yemen may become an even stronger terrorist base, threatening security worldwide.

Here we show that the nature of violence in Yemen has changed between 2005 and 2011 from being ethnically and religiously based to being dominated by the effects of increases in food prices on an impoverished population. During the period of ethnic and religious inter-group violence, geographical locations of incidents are consistent with a theory that predicts areas of violence based upon the geographical composition of the population [11, 12], building on a tradition of geographic analysis in social science [13-15]. In contrast, the later period of violence begins at the time of globally increasing food prices in 2007, and spread from areas of ethnic conflict in the north to the endemically poor southern part of Yemen.

Our results have immediate implications for strategies to reduce violence and limit the growth of terrorist influence. Rather than direct military and security operations, effective interventions may require eliminating the primary economic and social drivers of violence. First, the immediate economic drivers can be relieved by addressing the problems of the global food market, which has been implicated more broadly in the revolutions in North Africa and the Middle East [16-18]. Second, by providing partial internal autonomy to ethnic and religious groups, the origins of the longer term inter-group violence can also be alleviated [12].

The interventions we identify would not only address the growing security risks, but also improve the living conditions of millions of people, reducing severe poverty, social disruption and endemic violence. Indeed, these two goals are directly linked as the social and economic conditions are the origins of social disorder, in whose shadow terrorist activities can grow.

Our analysis of violence in Yemen begins from an understanding of the role of geography in conflict between distinct self-identifying groups defined by properties like ancestry, culture, language, and religion [11,12]. In this paper we use the term ethnic violence to describe this 
kind of inter-group conflict. Such violence is typically though not exclusively directed against or by civilians. When self-identifying groups are either sufficiently separated or sufficiently well-mixed, violence is unlikely. Separation limits inter-group friction, while integration inhibits inter-group alienation. Ethnic violence occurs most frequently in areas that have a certain intermediate degree of population separation, but in which control of the area is not separated accordingly, i.e. neither political nor physical boundaries exist to allow for local autonomy. In places where self-identifying groups separate into geographical patches of a critical size, in the range of 20-60 km, a group is able to impose its cultural norms, religious values, language differences and in-group social signaling within public spaces. These spaces may include public squares, markets, restaurants, places of worship and schools. However, when social expectations are violated because of the proximity of other ethnic domains, the resulting friction is likely to cause radicalization of some members of the population. Even a small radicalized minority is enough to lead to endemic conflict, and the propensity for violence becomes high. The violence may engage political and military components. Still, the origin of the conflict in the self-identity of the groups is likely to be manifest in violence directed against those who are not politically or militarily powerful. For patches larger than the critical geographical size individuals remain largely within their own domains and de facto local sovereignty exists. If patches are smaller than the critical size, ethnic groups cannot impose their own norms and expectations about behavior in public spaces, allowing for the peaceful coexistence of the multiple ethnic groups that are present. Natural and political boundaries can increase autonomy to allow for separation that can prevent violence in areas where it would otherwise occur. Tests of ethnic violence in various parts of the world have indeed shown that ethnic violence occurs in the vicinity of patches of a critical size without well-defined boundaries [11, 12].

In contrast to ethnic violence, social unrest reflecting socio-economic despair is often directed against authorities that fail to satisfy the most basic needs of the population, especially available or affordable food. Indeed, the relationship between food prices and social unrest has been demonstrated [16, 19-22]. Food riots around the world in 2007-8 and 2010-11 were triggered by steep increases in food prices. Since Yemen is one of the poorest countries in the Arab World [23], increases in food prices severely impact a large portion of the population [24]. According to the World Bank's 2007 Poverty Assessment Report, 35\% of the country's population is classified as poor [25]. 
In order to perform a more detailed and quantitative analysis we start by considering the ethnic geography of Yemen. There are four commonly described self-identifying ethnic and religious groups in Yemen: Zaydi Shiites, Ismaili Shiites, mainstream (Shafi'i) Sunnis and Salafi (Wahhabi) Sunnis. Together these groups are estimated to represent 99\% of the population (55\% Sunni and about $44 \%$ Shiite) [26]. Yemen's societal structure has a strong tribal aspect, especially in rural areas $[1,27]$. While neither tribal allegiances nor political attitudes necessarily align with their members' religious denomination [6], it is nevertheless reasonable to assume as a first approximation that conflict arises between selfidentified ethnic and religious groups. Obtaining data about the geographical distribution of these groups is difficult as there is no direct census and the distribution has changed in recent times, especially due to the spread of Salafism [28]. Moreover, since political and religious affiliations may be linked, various movements including the Moslem Brotherhood may have both political and religious connotations. For our analysis of ethnicity and violence we use spatial demographic data from 2004 [29] to identify the populated areas and an approximate map of the spatial distribution of the four major groups in 2000 obtained from a compilation of sources [30] to identify ethnic compositions, as shown in Figure 1. The approximate nature of the available data limits the precision of the calculations we perform. Demographic dynamics, specifically the spread of Salafism in recent years changed the sectarian associations across Yemen. Our conclusions only depend on very general features of spatial geography, specifically the presence of groups of a given geographic size in a region of the country. The conclusions are therefore robust to all but very specific localized changes relative to surrounding areas. This is a strength of our method, especially in application to areas where data is poor and changes are ongoing. Data on violent incidents was obtained from the Worldwide Incident Tracking System (WITS) [31] from which we selected the incidents that involved civilian casualties.

We calculated the propensity for violence in any given populated area by identifying patches of ethnic groups of a critical size of $56 \mathrm{~km}$. This size is consistent with the value that provides predictive success in other countries [11,12]. Mathematically we use a wavelet filter [11] that weighs the presence of ethnic types in a circular area around a focal point against the presence of ethnic types in the surrounding area. If ethnic types are well mixed or the whole area is populated uniformly by only one type, the output of the filter is small. However, if the inner area is populated by a different type than the surrounding area, forming 


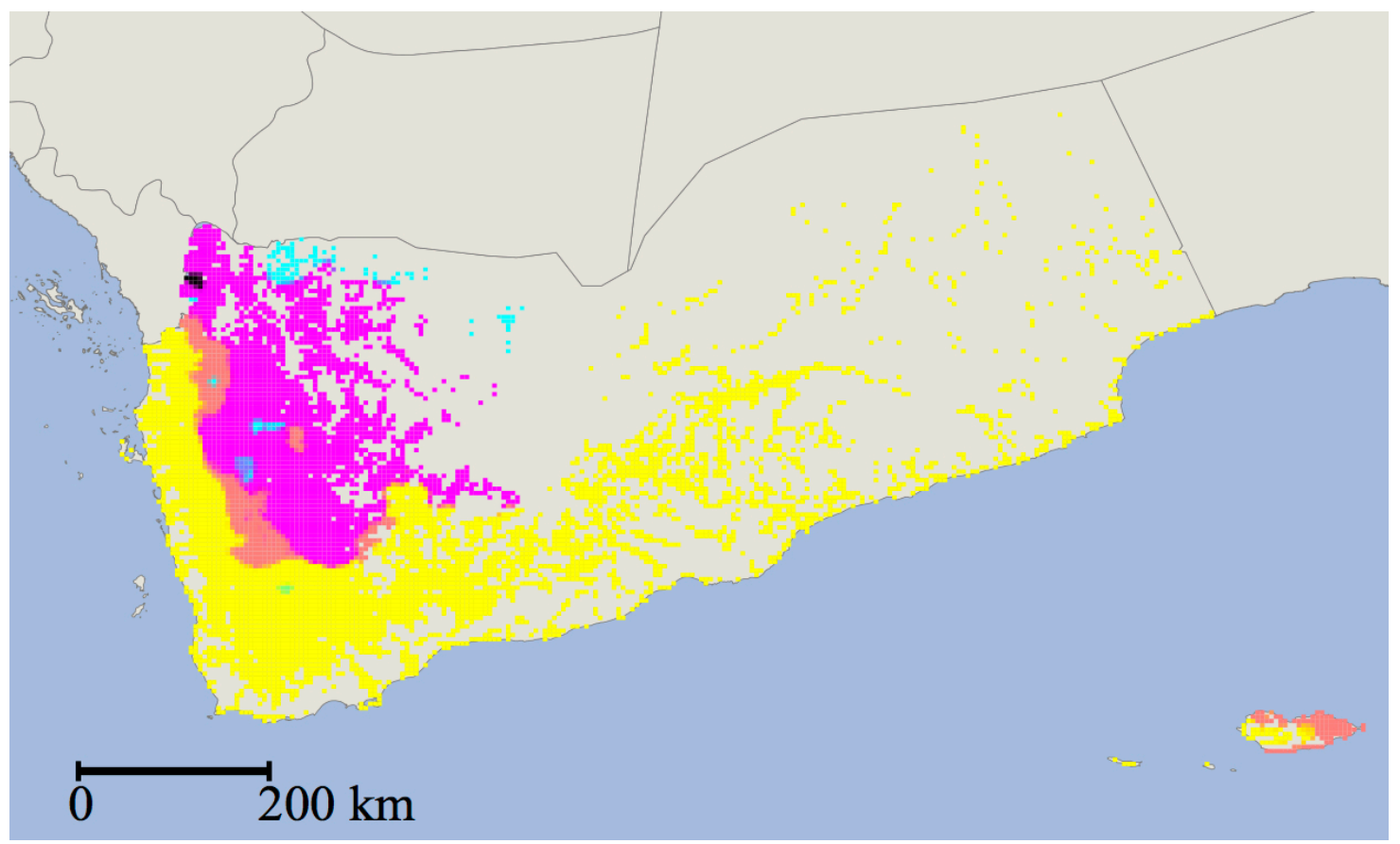

Figure 1: Estimated spatial distribution of major self-identifying groups in Yemen in 2000 [30]; Zaydi Shiite: magenta, mainstream Sunni: yellow, Ismaili: cyan, Salafi: black

an ethnic island or peninsula, the output will be high. We perform this analysis for focal points on a fine regular mesh throughout Yemen with results shown in Figure 2. Actual incidents of violence involving civilians are indicated for each year from 2005 through 2011. 

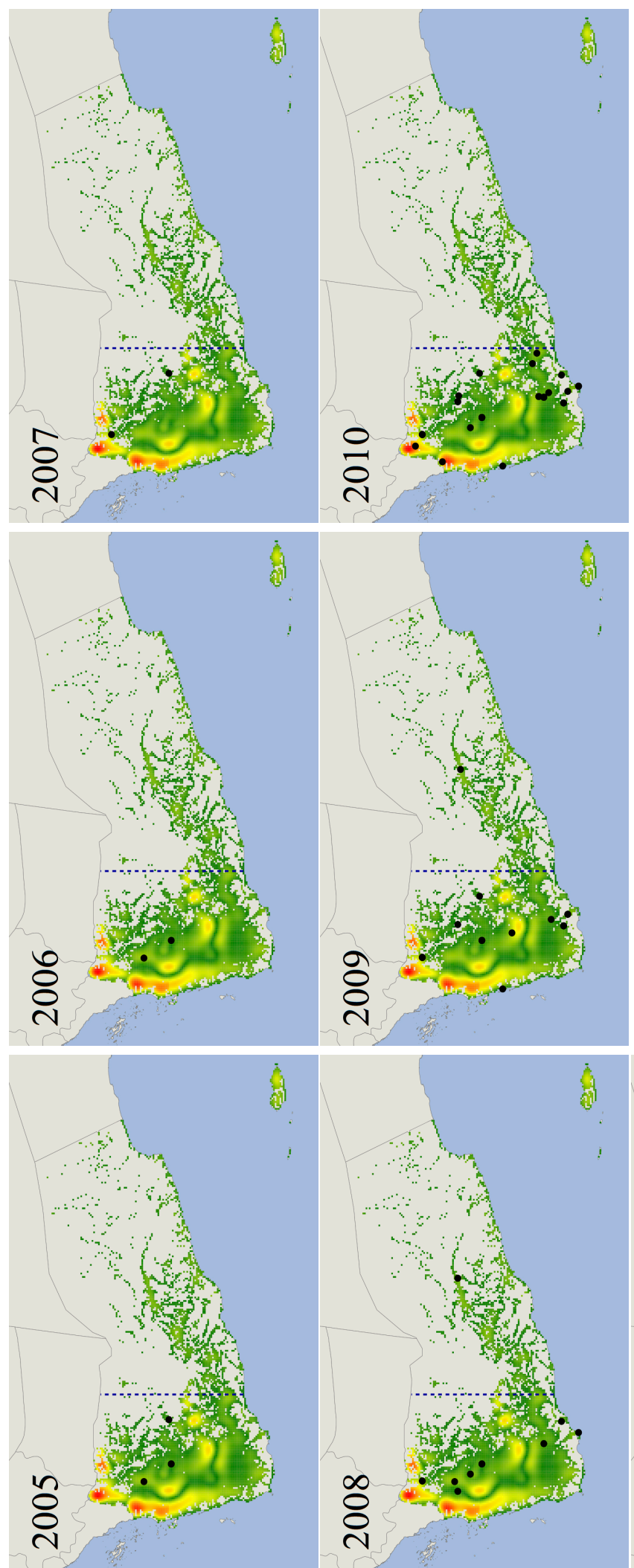

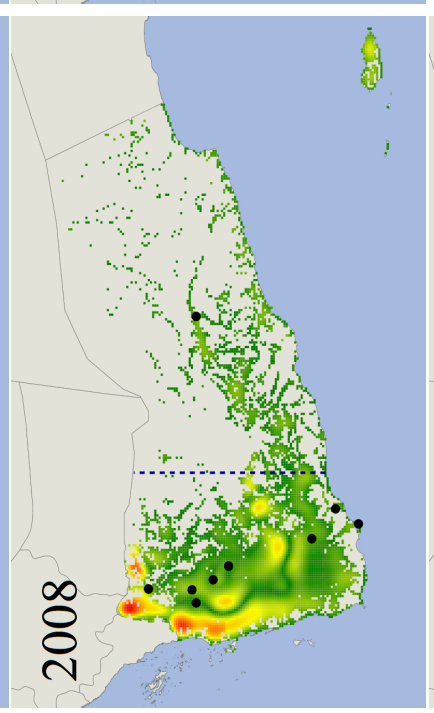

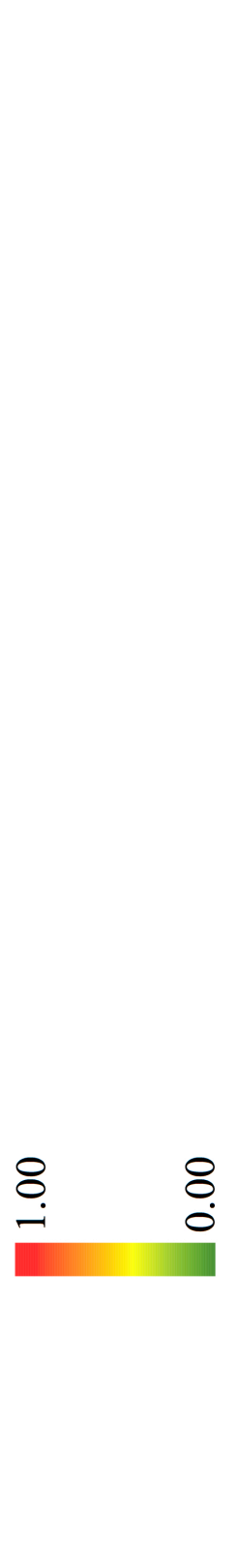

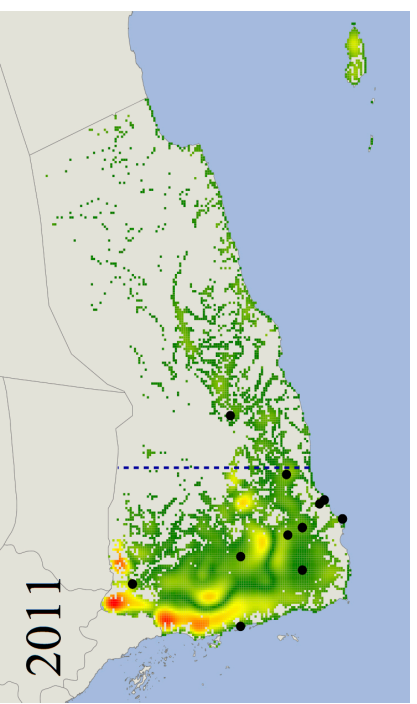

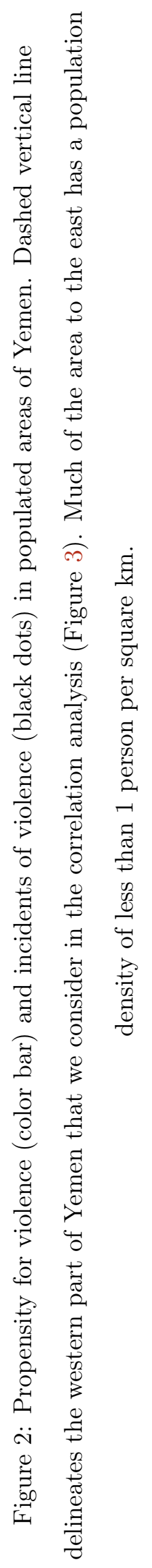




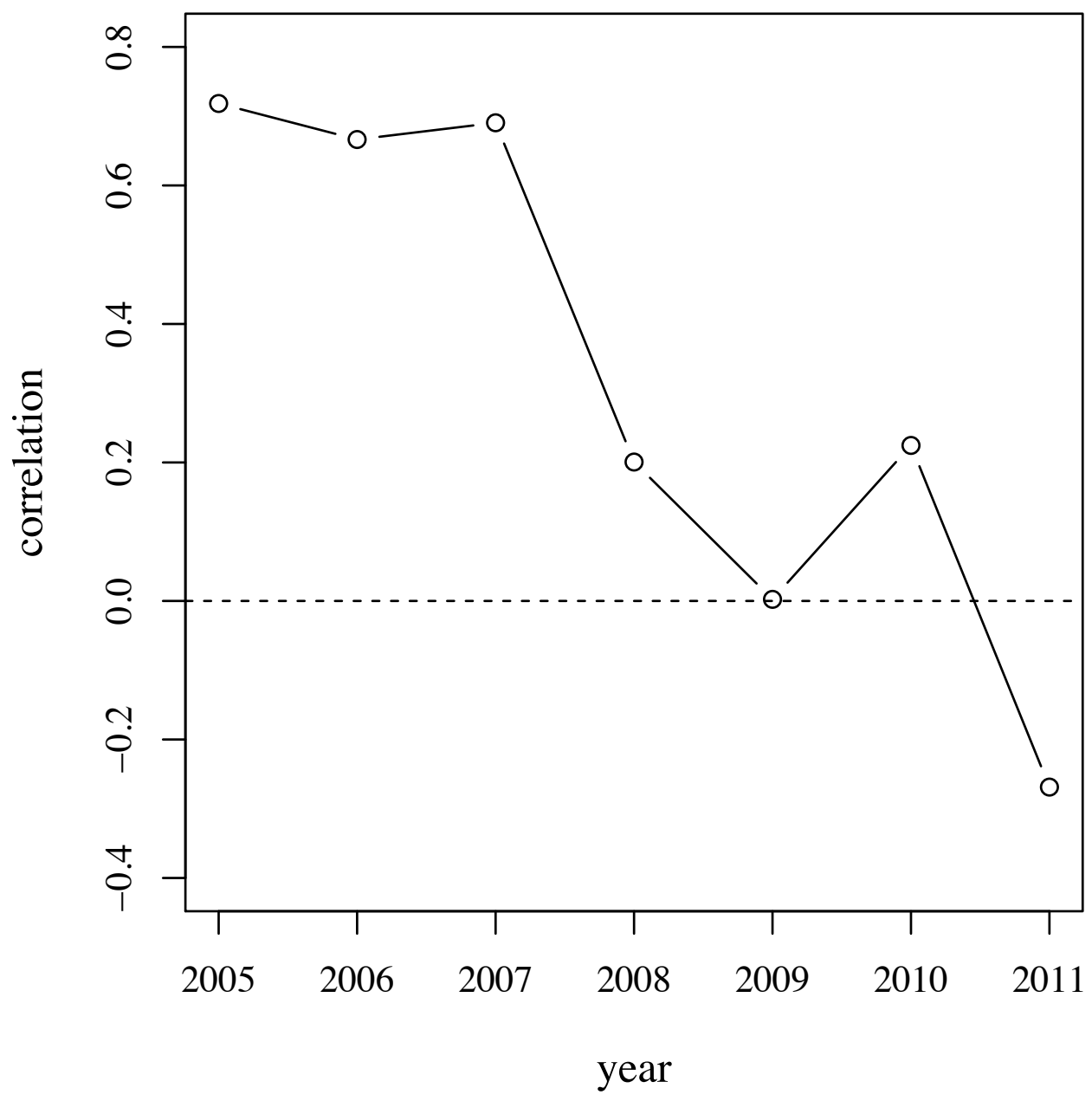

Figure 3: Correlations between shortest distances to locations of predicted and actual violence; the confidence values for the years 2005, 2006, and 2007 are $98.00 \%, 96.58 \%$, and $99.23 \%$, respectively.

We quantify the level of agreement between our prediction and the data on violent incidents by correlating maps of shortest distances to locations of violent incidents and locations of predicted violence. We calculate the distance to the closest violent incident and the closest location of predicted violence at every point on the spatial mesh for a given year. We consider a location of predicted violence to be any point where the violence potential is above a threshold of 0.48 (the average propensity to violence plus two standard deviations).

We performed the analysis for the western part of Yemen, in which most of Yemen's population resides (see vertical dashed line in Figure 2). Figure 3 shows the correlations between shortest distances to actual and predicted locations of ethnic violence in the west 
over time. The correlation values are approximately 0.70 for 2005, 2006, and 2007, and drop to between - 0.2 and 0.20 for 2008 through 2011, showing a distinct shift away from ethnicallymotivated conflict. The confidence values for the correlations in years 2005, 2006, and 2007 are $98 \%, 97 \%$, and 99\%, respectively. We calculate confidence intervals using 100,000 trials with random placement of the same number of predicted locations of violence within the western part of Yemen and compare the correlations between the corresponding maps of shortest distances. The correlation values for the years 2005, 2006, and 2007 are lower than reported in previous studies $[11,12]$, perhaps due to the limitations of the geographic ethnic data and reporting of incidents in the Worldwide Incident Tracking System for these years. However, the confidence values for 2005, 2006, and 2007 are still well above 95\%. Our results are consistent with reports that ethnic violence plays a significant role in Yemen resulting in the deaths of more than 2,000 people annually [32]. Some violence is politicized in the form of the Houthi rebellion, but it also has sectarian roots and manifests in violence against civilians in a manner characteristic of ethnic conflict [33-35].

The marked drop in correlations after 2007 indicates that the nature of the conflict changed and was no longer solely ethnically motivated. In order to identify the origins of violence after 2007 we turn to an understanding of social unrest in which food prices are a key component [16]. Figure 4 shows the global Food Price Index over time and the occurrence of food riots and revolutions associated with the Arab Spring [16]. The dates of the food riots in Yemen in early 2008 and 2011 are marked in red and coincide with similar events in many other countries. The co-occurrence of global food riots with large spikes in food prices is consistent with a causal role of food prices in social unrest. (An alternative hypothesis positing that the spread of Salafism caused the violence in the south is not supported by direct analysis, indicating they were not particularly involved [28].) Figure 4 shows that food riots in 2007-08 and 2010-11 were not a local phenomenon, but affected a broad spectrum of regions in Africa and the Middle East as well as Haiti and India. We can therefore understand the appearance of social unrest at these times based upon a hypothesis that widespread unrest is not necessarily related to governmental activities, or, in the case of Yemen, to terrorist actions. Instead, social unrest is induced by the government's perceived failure to provide food security to the population [16]. The poverty prevalent in Yemen [3], and southern Yemen's dependency on imported wheat [6, 24, 36], similar to Egypt and Tunisia [37], in combination with rising food prices, are very likely to have been 


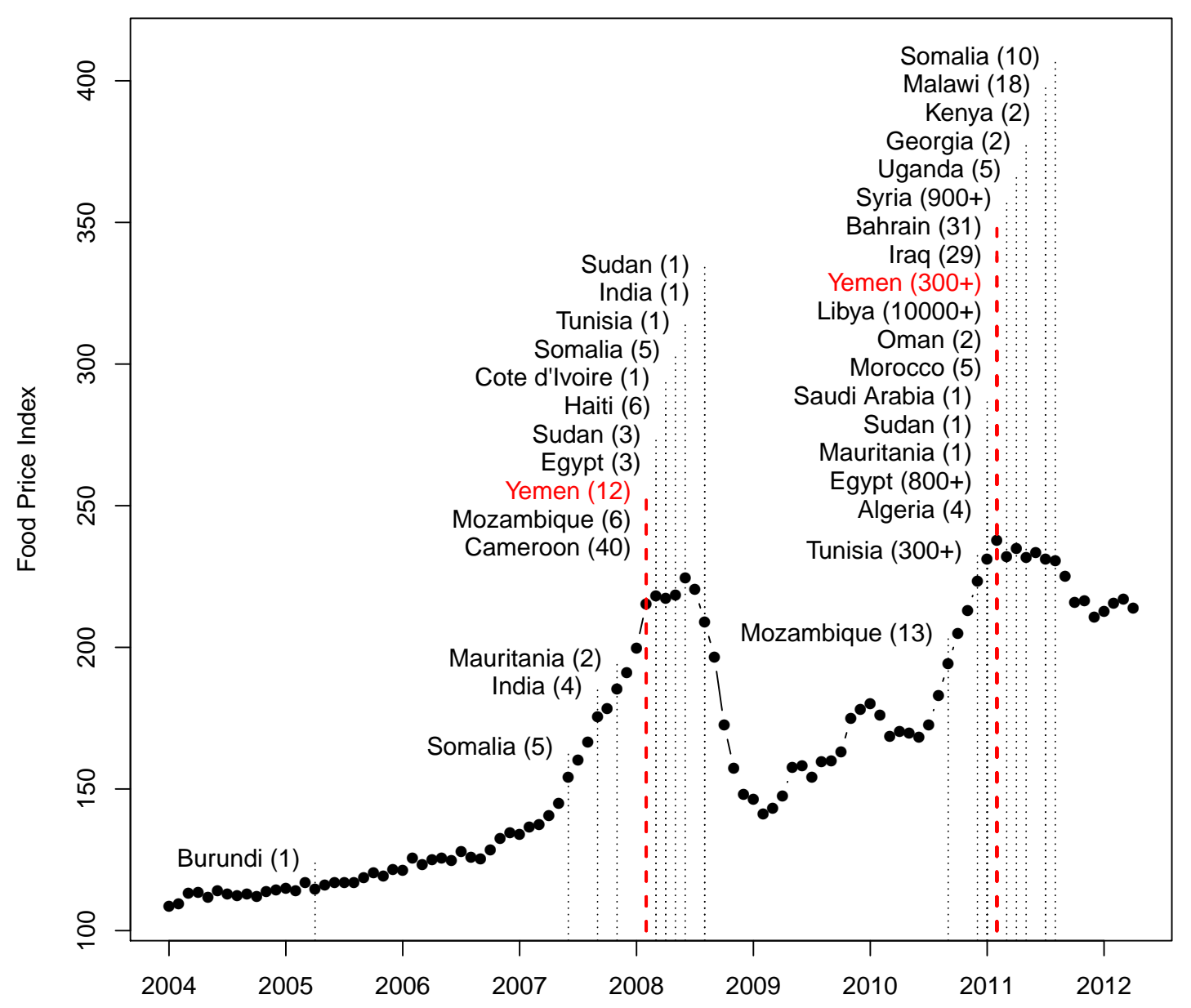

Figure 4: Global food price index and the occurrence of food riots (number of casualties in brackets); food riots in Yemen are marked red; reproduced with permission from [16]

the underlying trigger for violent incidents in 2008 and later.

Geographically, the violence in 2008 expanded from the north to the south. The southern violence can be understood from the recent political and economic history of Yemen. From 1967 through 1990 South Yemen existed as an independent state. The separation between North and South Yemen is partially, but not completely, according to ethnic regions. After unification in 1990, the north dominated and the south was economically marginalized. Ownership of resources was transferred to northern individuals and organizations [38-40]. The corresponding political disaffection manifested in a brief civil war in 1994. In 2007, during the first food price peak, political discontent coalesced into the Southern Movement, which was reenergized by food riots in 2010 to demand a wide range of economic and social concessions [41, 42]. While the expansion of violence to the south is a key change, poverty 
is also widespread in the north. An increase in violent activity in 2008 and 2010 in the north can be attributed to food based riots overlaid upon the preexisting ethnic conflict. Similar to other countries associated with recent revolutions in North Africa and the Middle East, the unrest based on food riots developed into a broader revolutionary process based upon persistent economic and social conditions, with implications for both local political instability and global terror.

Our work has identified two major sources of violence in Yemen: partial ethnic separation with poorly defined boundaries and unreliable food security for a vulnerable population. These conclusions have direct implications for policy.

The most urgent socioeconomic problem driving violence is high food prices. Recent work has shown that there is likely to be another food price bubble by the end of 2012 [43]. Based on this prediction conditions in Yemen will deteriorate if no mediating policy changes take effect to lower food prices. Current political efforts to broaden the governmental basis through assembling a National Dialogue Conference aim to tackle political grievances but do not address the problems of food prices. The most direct method to achieve food price stability is to provide subsidies as have been implemented in many countries in the face of the inability of the population to afford available food. Such subsidies are, however, difficult to afford for impoverished countries and would require external financing. More fundamentally, while many different factors have been considered for causing the rise of global food prices, a quantitative analysis has shown that the drivers of food price increases originate in US agricultural policies that are affecting food prices globally. These include two distinct domains of domestic policy. The first is subsidies for corn-to-ethanol conversion, which resulted in growth over less than a decade from negligible rates to $40 \%$ of the US corn crop being converted to ethanol [44]. More recently, concerns about their impact has led to the elimination of these subsidies as of December, 2011 [45]. However, regulations that specify the amount of ethanol to be produced continue [46] The second is the elimination of constraints on commodity speculation in 2000 [47], which led to rapid growth of speculative activity through commodity index funds that do not follow supply and demand, and result in speculative bubbles [48, 49]. The Commodity Future Trading Commission is in the process of reimposing constraints on commodity trading to avoid speculative bubbles [50, 51]. However, the market participants are seeking to dilute the impact of these new regulations [52-56] These examples show that increased attention to the impact of food prices and their role 
in global social unrest necessarily links global security planning and domestic agricultural policy.

The violence that is ethnic in nature could be dramatically reduced by increasing political independence by establishing internal country boundaries between ethnic groups [12]. The paradigmatic example of the use of internal political boundaries to successfully promote peace is that of the Cantons in Switzerland which were established to separate Catholic and Protestant populations at a time when conflict was prevalent. The success of this approach of internal autonomous regions can be considered a model for other areas of the world. The value of a federal system of governance to reduce the propensity for violence in Yemen has been recently suggested [57]. More political self-determination has been demanded by the Southern Movement [42] and would most likely be easier to implement than separate nations. One form of potential boundary is the implementation of road blocks, which are currently used by the government as well as by tribes [58], Al-Qaeda, and Ansar al-Sharia [59]. However, access control is met with hostility where the authority over group territories is not legitimized or established historically. Legitimizing partial autonomy in a context of central government power, in regions determined by the geographical distribution of the main ethnic groups, would be effective according to our analysis.

We have shown that science can directly analyze social disruption and violence and identify their causes, as well as provide recommendations about policy changes to mitigate them. Our framework enables us to consider violence within its socioeconomic context. Terrorist organizations proliferate in the power vacuum in countries in which the government is inherently unable to provide order. For the specific case of Yemen, insurgents benefit from and amplify existing social disruption as the government and military are caught up in conflicts stemming from food insecurity and ethnic differences. Food prices and ethnic conflict can be seen to play a direct role [60]. We recommend the implementation of jointly defined internal political boundaries, within which the different groups can enjoy a degree of self-determination, in addition to lowering food prices through within-country subsidies and global food policy actions, as these measures have the greatest chance of stabilizing Yemen.

We thank Jeb Boone and Charles Schmitz for helpful comments on the manuscript. This work was supported in part by AFOSR under grant FA9550-09-1-0324. 
[1] P. Dresch, Tribes, Government, and History in Yemen (Clarendon Press, 1989).

[2] P. Dresch, A History of Modern Yemen (Cambridge University Press, 2000).

[3] K. Fattah, Yemen: A Social Intifada In a Republic of Sheikhs, Middle East Policy 18, 79 (2011).

[4] P. Bernin, Yemen's hidden war, Le Monde Diplomatique (2009). Translated by Robert Waterhouse.

[5] C. Boucek, Yemen: Avoiding a downward spiral, The Carnegie Papers (2009).

[6] M. N. Katz, Breaking the Yemen - Al Qaeda connection, Current History 102, 40 (2003).

[7] Al Qaeda in the Arabian Peninsula (New York Times, 2012). http://topics.nytimes.com/top/reference/timestopics/organizations/a/al _qaeda_in_the_arabian_peninsula/.

[8] J. Masters, Al Qaeda in the Arabian Peninsula (Aqap) (Council on Foreign Relations, 2012).

[9] S. Phillips, What Comes Next in Yemen? Al-Qaeda, the Tribes, and State-Building (Carnegie Endowment for International Peace, 2007).

[10] A. B. Prados, J. M. Sharp, Yemen: Current Conditions and U.S. Relations (Congressional Research Service, 2007).

[11] M. Lim, R. Metzler, Y. Bar-Yam, Global Pattern Formation and Ethnic/Cultural Violence, Science 317, 1540 (2007).

[12] A. Rutherford, D. Harmon, J. Werfel, S. Bar-Yam, A. Gard-Murray, A. Gros, Y. BarYam, Good Fences: The Importance of Setting Boundaries for Peaceful Coexistence, arXiv:1110.1409v1 [physics.soc-ph] (2011). http://arxiv.org/abs/1110.1409.

[13] B. Berry, D. Marble, Spatial analysis: a reader in statistical geography (Prentice-Hall, Englewood Cliffs, NJ, 1968).

[14] R. Chorley, P. Haggett, eds., Models in geography (Methuen, London, 1967).

[15] D. Harvey, Explanation in geography (Edward Arnold, London, 1969).

[16] M. Lagi, Y. Bar-Yam, K. Z. Bertrand, Y. Bar-Yam, The food crises: a quantitative model of food prices including speculators and ethanol conversion, arXiv:1109.4859v1 [q-fin.GN] (2011). http://arxiv.org/abs/1109.4859.

[17] A. Ciezadlo, The New Arab Revolt: What Happened, What It Means, and What Comes Next 
(Council on Foreign Relations).

[18] L. R. Brown, The New Geopolitics of Food, Foreign Policy (2011).

[19] R. Arezki, M. Brükner, Food prices and political instability (2011). International Monetary Fund Working Paper.

[20] M. F. Bellemare, Rising food prices, food price volatility, and political unrest.

[21] R. Bush, Food Riots: Poverty, Power, and Protest, Journal of Agrarian Change 10, 119 (2011).

[22] J. Walton, D. Seddon, Free Markets and Food Riots (Blackwell, 1994).

[23] The world factbook (Central Intelligence Agency, Washington, DC, 2011).

[24] Yemen: Soaring food prices force more people below poverty line - WFP, Integrated Regional Information Networks (2008).

[25] Yemen Poverty Assessment, Vol. I: Main Report (The Government of Yemen, the World Bank, and the United Nations Development Program, 2007).

[26] Yemen (Institut Européen de Recherche sur la Coopération Euro-Arabe (MEDEA), 2007). http://www.medea.be/en/countries/yemen/yemen/.

[27] E. M. Manea, Islam et changement social (Editions Payot, Lausanne, 1998), chap. La tribu et l'Etat au Yémen, pp. 205-218. English translation at http://www.albab.com/yemen/soc/manea1.htm.

[28] L. Bonnefoy, Salafism in Yemen: Transnationalism and Religious Identity (C. Hurst \& Co. Publishers Ltd., 2012).

[29] Villages (Yemen Ministry of Public Health \& Population, 2004). http://www.mophpye.org/docs/Data/shp_villages_2004.zip.

[30] M. Izady, Yemen: Religious and ethnic composition http://gulf2000.columbia.edu/images/maps/Yemen_Ethno_Religious_lg.jpg.

[31] Worldwide Incidents Tracking System (U.S. National Counterterrorism Center, 2012). https://wits.nctc.gov/FederalDiscoverWITS.

[32] In-depth: Guns out of control: The continuing threat of small arms, IRIN (21 May 2006). http://www.irinnews.org/InDepthMain.aspx?InDepthId=8\&ReportId=41050.

[33] Yemen: Sectarian tensions rise, IRIN (30 November 2010). http://www.irinnews.org/Report/91245/YEMEN-Sectarian-tensions-rise.

[34] Yemen: Over 40 killed in sectarian clashes, IRIN (25 January 2012). http://www.irinnews.org/Report/94724/YEMEN-Over-40-killed-in-sectarian-clashes. 
[35] A. France-Presse, Yemen: Over 40 killed in sectarian clashes, Pakistan Today (27 November 2011). http://www.pakistantoday.com.pk/2011/11/27/news/foreign/20-killed-70-injuredin-yemen-ethnic-violence/.

[36] United States Department of Agriculture Foreign Agricultural Service, Production, Supply and Distribution Online (http://www.fas.usda.gov/psdonline/).

[37] North Africa Brief, FAO/GIEWS Global Watch (2011).

[38] Yemeni Civil War (1990-1994) (GlobalSecurity.org, 2000). http://www.globalsecurity.org/military/world/war/yemen1.htm.

[39] B. Whitaker, The birth of modern Yemen (2009). http://www.albab.com/yemen/birthofmodernyemen.

[40] Fault lines: Tracking armed violence in Yemen, Small Arms Survey Issue Brief (2010).

[41] Is South Yemen preparing to declare independence?, TIME Magazine (2011). http://www.time.com/time/world/article/0,8599,2081756,00.html.

[42] S. Day, Yemen on the brink - The political challenge of Yemen's Southern Movement, vol. 108 of Middle East Program (Carnegie Endowment for International Peace, Washington, DC, 2010).

[43] M. Lagi, Y. Bar-Yam, K. Z. Bertrand, Y. Bar-Yam, Update 2012 - The food crises: predictive validation of a quantitative model of food prices including speculators and ethanol conversion, arXiv:1203.1313v2 [physics.soc-ph] (2012). http://arxiv.org/abs/1203.1313.

[44] Production, Supply and Distribution (United States Department of Agriculture, Foreign Agricultural Service, 2012). http://www.fas.usda.gov/psdonline.

[45] R. Pear, After three decades, tax credit for ethanol expires (New York Times, 2012). http://www.nytimes.com/2012/01/02/business/energy-environment/after-three-decadesfederal-tax-credit-for-ethanol-expires.html.

[46] Federal and State Ethanol and Biodiesel Requirements (U.S. Energy Information Administration, 2007). http://205.254.135.7/oiaf/aeo/otheranalysis/ethanol.html.

[47] Commodity Futures Modernization Act of 2000 (Pub. L. 106-554, Sec. 1(a)(5) [H.R. 5660], Dec. 21, 2000, 114 Stat. 2763, 2763A-365) (U.S. Federal Government, 2000).

[48] F. Kaufman, The food bubble: How Wall Street starved millions and got away with it, Harper's Magazine pp. 27-34 (2010).

[49] J. Ghosh, The unnatural coupling: Food and finance, Journal of Agrarian Change 10, 72 
(2011).

[50] Position limits for futures and swaps, Federal Register 76, 71626 (2011).

[51] S. Patterson, J. Trindle, CFTC raises bar on betting, Wall Street Journal (2011).

[52] J. Trindle, CFTC may change application of speculative limits, Market Watch - The Wall Street Journal (2012). http://www.marketwatch.com/story/cftc-may-change-application-ofspeculative-limits-2012-05-17.

[53] S. Brush, CFTC proposes easing of Dodd-Frank speculation limit rules, Bloomberg (2012). http://www.bloomberg.com/news/2012-05-18/cftc-proposes-easing-of-dodd-frankspeculation-limit-rules.html.

[54] Speculative Position Limits, Futures Industry Association (2011).

[55] C. S. Donahue, Re: CFTC Proposed Rulemaking on "Federal Speculative Position Limits for Referenced Energy Contracts and Associated Regulations," 75 Fed. Reg. 4144 (Jan. 26, 2010), CME Group (2010).

[56] J. M. Damgard, Re: Position Limits for Derivatives (RIN 3038-AD15 and 3038-AD16), Futures Industry Association (2011).

[57] The roots of Yemen's uprising: Interview with Khaled Fattah, Studies in Ethnicity and Nationalism (31 July 2011). http://senjournal.wordpress.com/2011/07/31/the-roots-ofyemen $\%$ E2\% $80 \% 99$ s-uprising-interview-with-khaled-fattah/.

[58] A. Dawood, Bani Hushaish tribesment block Sana'a-Mareb road, Yemen Times (2012). http://www.yementimes.com/en/1561/news/673/Bani-Hushaish-tribesmen-blockSana\%E2\%80\%99a-Mareb-Road.htm.

[59] S. Qaed, A. Anees, Different armed groups govern Aden, Yemen Times (2012). http://yementimes.com/en/1564/report/718/Different-armed-groups-govern-Aden.htm.

[60] Arc of Convergence: AQAP, Ansar al-ShariÕa and the Struggle for Yemen, CTC Sentinel (21 June 2012). http://christopher-swift.com/publications/arc-of-convergence-aqap-ansar-alsharia-and-the-struggle-for-yemen. 